\section{Mejorar la educación médica pregraduada}

José Manuel Ribera-Casado

\title{
Improving undergraduate medical education
}

Desde que al inicio del siglo xx el 'Flexner report' revolucionó los programas curriculares del pregrado médico [1] han sido constantes los intentos de adaptación de éstos a las nuevas necesidades surgidas con posterioridad. Lo han sido tanto en lo que respecta a los contenidos doctrinales derivados de los avances tecnológicos y científicos, como en la adaptación de las nuevas formas de enseñanza a un contexto social determinado. Cuestiones como el mejor conocimiento de los fundamentos básicos de bioquímica, física o genética, la toma en consideración de los condicionantes sociales de la medicina, los progresos farmacológicos, la aparición de nuevas especialidades como la oncología o la geriatría, la incorporación a la medicina de la epidemiología y la estadística, la necesidad de disponer de unos conocimientos básicos en economía de la salud, la puesta en escena del respeto a los principios de la bioética, o la aplicación translacional de todo lo anterior, son algunos de los campos donde, permanentemente, se plantean alternativas que buscan adaptar los currículos a las necesidades del momento.

El reto es complejo. Superarlo implica asumir que el tiempo de formación médica no se puede estirar como el chicle. No se trata tanto de añadir información como de sustituir formas y contenidos que van quedando obsoletos. Eso choca con algunas mentalidades y con un buen sector del profesorado reluctante a que 'lo suyo' quede incluido en ese saco. El resultado es que el modelo tradicional se mantiene y las posibilidades de cambio se minimizan. Se ha hablado de perpetuar un premed syndrome, anclarse en una forma de cultura que entra en liza con el rigor académico e intelectual, con el pensamiento creativo, con la necesidad de colaboración y con la conciencia social [2]. Respondería al patrón lampedusiano de hacer como que se cambia para que todo siga igual.
Since the 'Flexner report' revolutionised the curricula of undergraduate medical studies in the early 20th century [1], numerous attempts have been made to adapt them to the new needs that have emerged since then. This refers both to the doctrinal contents derived from technological and scientific advances and to adapting new ways of teaching to a particular social context. Some of the fields in which alternatives have continually been proposed with the aim of adapting the curricula to the particular needs of each time include: issues such as a better knowledge of the basic foundations of biochemistry, physics or genetics; taking into account the social conditioning factors of medicine; advances in pharmacology; the appearance of new specialities such as oncology or geriatrics; the incorporation of epidemiology and statistics into medicine; the need to have some basic knowledge of health economics; respecting the principles of bioethics; or the translational application of all the above.

The challenge is a complex one. Rising to it means accepting that time in medical training cannot be stretched like a piece of chewing gum. It is not so much a question of adding information but rather of replacing forms and contents that have become obsolete. This clashes with some ways of thinking and with a considerable number of teachers who are reluctant to see how 'their matters' end up being placed in the same category. The result is that the traditional model is maintained and the chances of any change taking place are minimised. There has been talk of perpetuating a premed syndrome, of becoming anchored in a form of culture that is at odds with academic and intellectual rigour, with creative thinking, with the need to collaborate and with social awareness [2]. This would respond to the Lampedusan pattern of pretending to undertake changes while everything in fact remains the same as ever.
Catedrático Emérito de Geriatría; Facultad de Medicina; Universidad Complutense de Madrid. Académico de la Real Academia Nacional de Medicina. Madrid, España.

E-mail: josemanuel.ribera@ salud.madrid.org

Conflicto de intereses: No declarado.

Conflict of interests: None declared.

(C) 2013 FEM 
Periódicamente aparecen en revistas de primer nivel experiencias locales atractivas y contrastadas que pueden servir de referencia en este terreno, por ejemplo, el denominado 'programa sobre humanidades y medicina' que se viene aplicando en Mount Sinai desde hace unos años [3]. También el llamado 'plan de Bolonia', glosado en estas mismas páginas [4], representa un intento de buscar puntos comunes que faciliten las reformas necesarias en nuestro continente. En la misma línea se expresan otras muchas opiniones, como las recogidas en una publicación reciente de carácter general donde se revisan distintas experiencias en este sentido planteadas en diferentes lugares del mundo [5].

En ese marco debemos considerar muy positiva la existencia en España desde hace décadas de la Sociedad Española de Educación Médica, entre cuyos fines se encuentra dinamizar este campo a través de congresos y publicaciones donde exponer, contrastar y discutir experiencias que ayuden a mejorar la formación de nuestros estudiantes. De eso trata el trabajo que da origen a estos comentarios. 'Enseñar a ser médicos' es un estudio realizado en los hospitales con docencia de pregrado de la Universidad Complutense de Madrid, que pide la opinión de los profesionales implicados y cuyo número de respuestas fue lo suficientemente alto como para poder considerarse representativo [6-8].

Lo primero que llama la atención es que las respuestas son bastante similares con independencia de quien las emite: catedráticos, profesores titulares, profesores asociados, personal médico sin reconocimiento docente y médicos residentes. Los resultados corroboran algunas de las ideas más aceptadas en nuestro medio en relación con el tema. Se proporciona al alumno una información adecuada y actualizada, mientras que resulta insuficiente la enseñanza clínica práctica. Se insiste en la necesidad de mejorar los métodos de evaluación, destacando el papel que los exámenes clínicos objetivos estructurados (ECOE) pueden desempeñar en este terreno. También se insiste en la necesidad de incorporar en proporciones crecientes las nuevas tecnologías a todo el proceso de aprendizaje. En el alumno existe una fijación en el examen de médico interno residente a la hora de priorizar sus intereses de aprendizaje. Los autores ponen énfasis en la importancia de conseguir una mayor motivación por parte de todo el profesorado a la hora de comprometerse en lo que conocemos como enseñanza práctica dentro del marco del hospital docente y en el papel que representa en este sentido el reconocimiento académico y social de su labor educativa.
From time to time top-level journals report attractive and proven experiences conducted on a local basis that may serve as a reference in this field. An example of this could be the so-called 'Humanities and Medicine Programme', which has been applied at Mount Sinai for some years now [3]. The socalled 'Bologna plan', which has been discussed in this same publication [4], also represents an attempt to find common points that facilitate the reforms that are needed in our continent. Many other opinions run in a similar direction, such as those recently reported in a mainstream publication that deals with different experiences of this kind carried out around the world [5].

In this context the existence of the Spanish Society for Medical Education should be seen as something very positive. Founded several decades ago, some of the aims of the Society include stimulating this field by means of congresses and publications that provide an opportunity to present, test and discuss experiences that help to improve our students' training. And that is what the work that gave rise to these comments is about. 'Teaching how to be a doctor' is a study conducted in hospitals offering undergraduate teaching by the Universidad Complutense de Madrid, in which professionals were asked for their opinion and which received a sufficiently high number of responses to allow it to be considered representative [6-8].

The first thing that stands out is the fact that the answers are quite similar, regardless of who they were given by: university professors, senior lecturers, associate lecturers, medical personnel who are not involved in teaching, and resident physicians. The findings corroborate some of the ideas that are most widely accepted in our setting in relation to this topic. Students are provided with suitable up-to-date information, while practical clinical teaching is insufficient. The emphasis is again placed on the need to improve methods of assessment, with special attention paid to the role that objective structured clinical examinations (OSCE) can play in this field. The need to incorporate increasing amounts of the new technologies across the whole learning process is another point that needs stressing. Students have a fixation on the medical resident exam when it comes to prioritising their learning interests. The authors underline the importance of achieving greater motivation on the part of all teaching staff when it comes to committing themselves in what is known as practical teaching within the context of the teaching hospital. Likewise, another essential point is the role played by the academic and social recognition of their educational labours. 
Queda fuera del estudio -y merecería la pena llevar a cabo un trabajo similar al respecto- todo lo referido a la enseñanza preclínica y su integración con la propia enseñanza clínica, un campo en el que probablemente la necesidad de reforma curricular es aún más apremiante. En todo caso, los resultados de este trabajo tienen en sí mismos interés más que suficiente como para que aquellas entidades implicadas en la materia, con la conferencia de decanos y el ministerio correspondiente a la cabeza, sean sensibles a sus conclusiones. Por último, destacaré el interés que en tiempos de crisis como los actuales tiene -como ha sido el caso- el hecho de poder contar con el apoyo de fundaciones privadas abiertas al mundo de la sanidad y de la educación a la hora de llevar a cabo proyectos de investigación como el que ha dado lugar a estos comentarios.
Although it would be interesting to carry out a similar study on the subject, everything to do with preclinical teaching and its integration with clinical teaching itselffalls beyond the scope of the study, despite being a field in which the need to reform the curricula is even more pressing. In any case, the results of this work are interesting enough for organisations involved in the matter, led by the conference of deans and the corresponding ministry, to take its conclusions into account. Finally, in times of crisis such as those we are currently undergoing, I would like to highlight the importance of being able to count on the support of private foundations that display their openness to the world of healthcare and education when it comes to carrying out research projects such as the one that has given rise to these comments.

Bibliografía / References

1. Cooke M, Irby D, Sullivan W, Ludmerer JM. American medical education 100 years after the Flexner report. N Engl J Med 2006; 355: 1339-44.

2. Kanter SL. Toward a sound philosophy of premedical education. Acad Med 2008; 83: 423-4.

3. Muller D. Reforming premedical education -out with the old, in with the new. N Engl J Med 2013; 368: 1567-69.

4. Sociedad Española de Educación Médica (SEDEM), Associació Catalana d’Educació Mèdica (ACEM), Sociedad de Educación Médica de Euskadi (SEMDE), Sociedad Aragonesa de Educación Médica (SADEM). Recomendaciones para un nuevo proceso de reforma curricular en las facultades de medicina españolas. Educ Med 2005; 8: 3-7.

5. Minué S. El cambio del paradigma educativo. El Médico 2013; 1143 (mayo): 14-9.

6. Millán Núñez-Cortés J, Gutiérrez-Fuentes JA. Enseñar a ser médicos: un análisis de opinión de los médicos implicados en la docencia de la clínica práctica (I). Conclusiones del análisis cualitativo y metodología para un estudio cuantitativo. Educ Med 2012; 15: 143-7.

7. Millán Núñez-Cortés J, Gutiérrez-Fuentes JA. Enseñar a ser médicos: un análisis de opinión de los médicos implicados en la docencia de la clínica práctica (II). Análisis cuantitativo de la opinión de médicos implicados en la docencia clínica práctica. FEM 2013; 16: $119-24$.

8. Millán Núñez-Cortés J, Gutiérrez-Fuentes JA. Enseñar a ser médicos: un análisis de opinión de los médicos implicados en la docencia de la clínica práctica (III). Perspectivas futuras derivadas del análisis de opinión de médicos implicados en la docencia clínica práctica. FEM 2013 [in press]. 